\title{
Acceptance of a Proposed Model Based on Using Web 2.0 for Developing English Writing Skills
}

\author{
Dalal Al-Sufyani, MA student \\ Mohammed Al-Sofyani, PhD, Assistant Prof.
}

College of Education, Taif University, Taif, Saudi Arabia

doi: 10.19044/esj.2016.v12n34p205 URL:http://dx.doi.org/10.19044/esj.2016.v12n34p205

\begin{abstract}
The study aimed at designing a proposed model for developing English writing skills using web 2.0 tools and exploring its acceptance level from students' and instructors' perspectives. The study adopted the descriptive methodology. Eight female instructors responded to the instructors' questionnaire. Also, twenty female students responded to the students' questionnaire. To analyse the quantitative data, the means of participants' respondents were calculated.

The most important results were both students and instructors who participated in the current study accepted the proposed model. Based on the results of the study, the most important recommendations were: using technology, especially the proposed model in teaching at ELC.
\end{abstract}

Keywords: Web 2.0, blog, Google Docs, writing skills, English Language Centre

\section{Introduction}

Kingdom of Saudi Arabia provides a special care for teaching and learning the English language, because the English language is considered as a language of science and knowledge. It facilitates communication with most of other nations. Al-Seghayer (2014) indicated that article Fifty of the Educational Policy in the Kingdom of Saudi Arabia states that students ought to gain (be taught) at least one foreign language to be able to communicate with people of other cultures for contributing to spread the message of Islam and serving humanity.

He mentioned that "English is used as an instruction delivery language in most university departments in areas such as science, medicine, engineering, allied health, and technical subjects. So, English language is very important to ensure Saudi Arabians are competitively educated and trained at international level" (Al-Seghayer, 2014:143). 
"Because language is infused into all aspects of the teaching of science, students, whose knowledge of English is limited, are likely to have difficulty accessing scientific concepts and expressing their understanding of these concepts in oral and written language" (Cummins, 2009:1). Academic success can be predicted through writing skill. It is required to take part in civic life and in the global economy (Graham \& Perin, 2007). But it is difficult to acquire by the second language learners (Barkaoui, 2007). "English as a second language (ESL) students face many difficulties and stresses in their academic writing" (Al Fadda, 2012: 123). AL-Khairy (2013) mentioned that it is recommended to motivate the students to use English with the teachers as well as with each other, introduce modern and novel teaching techniques, and equip the classrooms with necessary audio-visual aids as some necessary steps to solve the students' academic writing problems.

E-learning allows implementing the previous suggested solutions. It becomes as an important pillar in the age of knowledge. Learning is considered as a fundamental brick for developed nations and its continuous developing. E-learning adopts that and provides knowledge for all to meet the vision of development leaders towards sustainable development of the individuals and society.

In the lights of that, e-learning tools vary to keep pace with needs. So, web 2.0 tools, or what is called second-generation technology, create distinguished learning and teaching environment allowing experiences exchanging and information sharing. These tools create communication means between the teacher and his students and the student and his colleagues to enhance the learning process inside and outside the classroom. This kind of tools comes as a solution to practice the English language in the society which its individuals speak Arabic as an official language. These tools target four language skills: speaking, listening, reading, and writing.

\section{Statement of the Problem}

According to Jahin and Idrees (2012: 12), most Saudi learners did not have the desired level of proficiency in English language especially in productive skills". AL-Khairy's study (2013: 1) reveals that "Saudi Englishmajor undergraduates are very weak in writing skills and commit lots of errors in their academic writings". Using traditional teaching methods could be a reason for weakness in writing skills among students (Javid and Umer, 2014). In addition, there are many studies that represent using web 2.0 tools as a solution to overcome this problem such as Edwards (2011), Krajka (2012), Aljumah (2012), and Aydin (2014). So, this study was conducted to design a proposed model for developing female students' English writing skills and exploring its acceptance level from instructors' and students' 
perspectives. The study will address only two web 2.0 tools which are blogs and Google docs because of their effectiveness in teaching English writing skills (Zhou et al., 2012; Hedin, 2012; Arslan,2014). The current study differs from the earlier studies in using the two tools (blogs and Google Docs) together for the Saudi female students. It addressed the following questions:

1- What is the acceptance level of the proposed model from the students' perspective?

2- What is the acceptance level of the proposed model from the instructors' perspective?

\section{Literature Review Writing Skills}

Writing is a mean to communicate and translate ideas into language (Bader, 2007). It is an ideas' graphic representation, social activity, and an important skill for both language learners and native speakers (Mekki, 2012). Writing is both private and public skill at the same time. It is private because of its solitary nature during composition, but it is public because of its publishing for an audience. (Broughton et al., 2003). "Writing is one of the most difficult skills that second-language (L2) learners are expected to acquire, requiring the mastery of a variety of linguistic, cognitive, and sociocultural competencies" (Barkaoui, 2007; 35). Kirby and Crovitz (2013; 11) said that "teaching writing can be frustrating and challenging, but it can also be rewarding and a breath of fresh air in a rather stagnant educational context".

During writing, students involve in many activities to produce a text. In the process writing approach, writing is treated as a process, not as a completed product (Bayat, 2014). Barber et al. (2006) indicated that writing process consists of the different stages a writer goes through for developing a piece of writing. These stages are: pre writing, drafting, revising, editing and publishing.

\section{English writing for ESL / EFL learners}

Adults can both learn and acquire the second language. With a strong first language literacy skills, they may learn the second language easily (Ali, Jahin \& Al-Shareef, 2013). But Arabic is different from English in its spoken and written forms (Al Fadda, 2012). "[Students] must master the content and concepts in English, write through a language which they may not fully command and within a cultural context that is completely different from their own" (Mohamed \& Zouaoui, 2014:152). English writing difficulties such as lack of vocabulary, poor spelling, L1 interference and a poor understanding of grammatical structure may face students (Farooq, Uzair-UL-Hassan, \& 
Wahid, 2012). Even though educational policy in Saudi Arabia concerns about teaching English language, a number of researches approved students' weakness in acquiring English writing skills. Al-Khairy (2013) found that Saudi English-major undergraduates are very weak in writing skills. They commit lots of errors in their academic writings. They are usually engaged in sentence-level or at the maximum at a paragraph-level academic writing. They do not realize the importance of writing different kinds of essays. Javid and Umer (2014) approved that Saudi learners of English as a foreign language (EFL) are weak in choosing right lexical items, organizing of ideas and using grammar. They make mistakes in using prepositions, spellings, irregular verbs, articles, punctuation, suffixes and prefixes. Jahin and Idrees (2012: 10) found "a highly significant correlation between participants' writing proficiency levels and their overall English language proficiency". Ahmad (2012) mentioned that the reason is neglecting students' different learning styles. Huwari and Al-Khasawneh (2013: 1) "revealed that grammatical weakness, knowledge and understand, less practice and educational background" were the main reasons behind the weakness of students' writing. Al-Qurashi (2009: 57) showed that studying writing as a process, and receiving peer feedback can improve students' writing skills. So, methods of teaching writing could be updated. Group work strategies may enhance students writing skills. Ahmed (2012) proved that using different learning style can develop EFL Saudi students' writing skills. Al-Khairy (2013) and Javid and Umer (2014) suggested that it is recommended to increase writing courses, motivate students to use English with the teacher as well as with each other, introduce modern teaching techniques and methods, equip the classrooms with audio-visual aids, tailor the course contents according to students' needs, introduce the group / pair work and peer correction and motivate students to use dictionaries frequently.

\section{Collaborative Writing Can Be a Solution}

In collaborative writing, students work together in pairs or in groups to write a text. Speck (2002) mentioned that collaborative writing can be a useful tool to help students to learn actively. Stroch (2005) showed that collaborative writing provides students with the opportunity to interact with different aspects of writing. It enables students to give and receive immediate feedback on language which cannot exist in individual writing. Pae (2011) conducted a study to investigate which is better; collaborative writing or individual writing. He found that collaborative writing was better than individual writing in terms of fluency, complexity, and easy score, while the results for accuracy were mixed.

Traditionally, each individual's work, either written on paper or on a word processing program, has been exchanged is called collaborative 
writing. But new various technologies appear and have a large impact on learning and collaborative writing. Various web 2.0 technologies such as blogs, wikis, photo or video sharing sites, and social writing platforms are considered easy-to-use programs. By using social writing platforms, including wikis, Socialtext, and web-based office programs such as Google Docs, multiple writers are able to edit and revise the same document together (Pae, 2011).

\section{Web 2.0}

The Internet has transformed from a read-only environment (Web1.0) to a read-write environment (Web 2.0) with the new social-sharing applications (Rosen \& Nelson, 2008). Solomon and schrum (2007: 13) defined Web 2.0 as "an invented term, coined in 2004. It encompasses the growing collection of new and emerging Web-based tools". They mentioned that many of these tools are used for accessing rather than installing the software on computers. Also, Web 2.0 tools "allow multiple users to participate: editing, commenting, and polishing a document collaboratively rather than working alone" (Solomon and schrum,2007: 13). In the light of the previous definition, Web 2.0 can be defined as a new technology which not only gives a chance for the users to read, but also to generate, share information and to collaborate in creating information.

Web 2.0 has three defining characteristics: user participation, openness and network effects. (Witteman\& Zikmund-Fisher, 2012: 3734). In addition, Solomon and schrum (2011) talked about the eight Cs which can be considered as characteristics for web 2.0. There are: communication, collaboration, connectedness, communities of learners, convergence, contextualization, cloud computing, cost-free (or almost free).

Solomon and Schrum (2007) mentioned that using web 2.0 tools for education causes a transformation in thinking because of promoting creativity, collaboration, and communication. So, using web 2.0 tools provides students with $21^{\text {st }}$ century skills. In addition, using web 2.0 tools globalizes knowledge. Grosseck (2009) indicated that teachers with using web 2.0 can collaborate with their own students, colleagues, others' students and community members from around the world.

\section{Web 2.0 and Connectivism theory}

Siemens (2005) mentioned that most learning theories such as behaviourism, cognitivism, and constructivism had assumed that learning occurs inside a person. These theories neglected learning that occurs outside

of people. Using technology in learning process moved learning theories into a digital age. In digital age, we connected everything to everything. Siemens (2005:4) said "A network can simply be defined as connections between 
entities." In the light of this Siemens coined the new theory which is Connectivism. According to him, in Connectivism theory, there is a concern about learning environment. The way of learning is observed to understand the learning process. Connectivism theory focused on opinions' diversity, learning which happened outside the people, the connections between information for continuous learning, up-to-date knowledge, and students' ability for decision-making.

\section{Web 2.0 Tools and Writing Skills}

There are many forms of web 2.0 tools. In the current study, the focus was on the web 2.0 tools which were used for teaching or developing English writing skills in the previous researches. These web 2.0 tools were Twitter, Forums, EtherPad, Google Docs, Facebook, Wiki, and Blog. To decide which one will be used, the researcher put some points into consideration which were:

1- giving teacher feedback and peer feedback.

2- enabling collaborative writing.

3- writing for the audience.

4- writing long texts.

5- providing a platform for various educational sources.

Twitter enabled only 140 text characters per a tweet (Grosseck \& Holotescu, 2008), so it was excluded because the need for writing long texts. On one hand, blogs, forums and Facebook can be used as platforms. But just the owner can post on the blog while in forums anyone of the members can write a new post. So, controlling in blogs made it more suitable than forums for the educational purposes. Also, it is easy to find old articles in blog unlike Facebook.

On the other hand, Google Docs, Wiki, and EtherPad enabled really real-time collaborative writing. But Google Docs provided more privacy than Wiki or EtherPad. Anyone had the URL of EtherPad or Wiki can edit the document. Gann (2014: 33) mentioned that "while Google Docs have various privacy settings for viewing and for editing privileges, EtherPads have none. Anybody who has the URL can view and edit an EtherPad document. They can also engage in chat completely anonymously".

Ford (2007:8) mentioned that "The traditional definition of a blog is of a special kind of website consisting of regular entries or posts arranged in reverse chronological order - that is with the most recent post at the top of the main page." Solomon and Schrum (2007) indicated that through blogging educators can share their ideas and their works freely. Blogging can help students to improve their writing skills and learn from each other. By creating a learning community, students can offer their opinions or add information and become confident in sharing what they know. 
Blogs are effective journal tools for developing English writing skills (Aydin, 2014; Arslan, 2014; Ting, 2015). Students have positive attitudes toward using the blog as a tool for teaching (Wu \& Wu, 2011; Aljumah, 2012; Kitchakarn, 2012; Said et al., 2013; Arslan, 2014; Aydin, 2014; Ting, 2015). Using blogs for teaching enables interaction between the students and the lecturer and the students with each other. This characteristic helps to receive feedback from both teachers and peers (Kitchakarn, 2012; Yunus et al., 2013; Said et al., 2013; Arslan, 2014; Ting, 2015). Using blogs for teaching can be synchronously during the class meetings or after class meetings or both in class and after class meetings (Wu $\& W u, 2011)$. Using blogs in teaching enhances students' creative and critical thinking skills (Kitchakarn, 2012).

However, some factors deter students and teachers from using blogs for teaching writing. According to (Lin et al., 2013; Yunus et al., 2013; \& Arslan, 2014), these factors are:

a- Students' low English proficiency.

b- Feelings of worry and embarrassment from blogging to the public.

c- Teachers' lack of time.

d- $\quad$ Students' lack of skills.

e- Less participation from the students.

f- Having access to the internet.

g- $\quad$ Students' lack of internet in using computers.

On the other hand, Chinnery (2008:5) defined Google Docs as "collaborative web-based word processing. Essentially, it is like a free webbased version of Microsoft Word". Kieslinger et al., (2008) indicated that Google Docs can be used collaboratively by a group of students to create a project which has one or more of the most common knowledge artefacts: word documents, spreadsheets, or presentations. Moreover, by using Google Docs, Lombard and Porto (2010) mentioned that teachers can publish announcements about upcoming assignments and check student progress interactively. Teachers can give guidance for their students during their work.

Google Docs is a good and an effective teaching tool for collaboration, especially in an out-of-class activity (Edwards, 2011; Krajka,2012; Zhou et al., 2012; Hedin, 2012). It supports students to help one another in learning without restriction of time and place (Suwantarathip $\&$ Wichadee, 2014). Students have positive attitudes toward using Google Docs for collaborative writing (Edwards,2011; Brodahl et al., 2011; Zhou et al., 2012; Curtis,2013; Suwantarathip \& Wichadee, 2014). Google Docs enables both peer feedback and teacher feedback (Hedin, 2012; Lin \& Yang, 2013). It also provides students with self-correction which made it easier for their peers to edit the last version of their work (Curtis, 2013). Google Docs 
allows sending and receiving instant update on the document and constant access to the online document which enables group collaboration in real-time (Edwards, 2011). Google Docs provides equal contribution, and students show high responsibility about their written assignments (Swantarathip and Wichadee, 2014).

During using Google Docs, students may face some technical problems, and institutional and administrative constraints (Brodahl et al. 2011). Some challenges emerge while using Google Docs such as periodic missing data from the screen and an accidental lag that occurred during the course of writing online (Lin \& Yang 2013).

Finally, Sofia (2012) explored enhancing ESL learners' technical English writing skills with Google Docs and blogs. The data were analyzed qualitatively based on pretests, continuous assessment tests and post tests. 34 Indian students participated. The results indicated that students had a positive experience in Google Docs and blogs. The combined use of these two tools offered promising benefits to ESL learners as they collaboratively wrote and showed remarkable improvement in their writing skills. Students used Google Docs for collaborative writing process and blogs for publishing writing artefact.

To Conclude, writing skill is an important productive skill that gives a chance to communicate with others. Also, it is a necessary skill in academic life. Even though, it is difficult to learn by the EFL and ESL learners. They may face problems such as: choosing proper words, using correct grammar structures, and generating and organizing ideas. This is caused by first language interference, traditional teaching methods, low-level of proficiency, and less practice outside the classroom. Many studies grow up to solve these problems. Preparing students for writing and encouraging them engage in writing process may help to overcome these challenges. Collaborative writing appeared as a solution which enables interaction between students and their instructors and the students with each other. Both instructors' and peers' feedback help students to develop their English writing skills.

Technology facilitates collaborative writing. Web 2.0 technologies as an example allow interacting and exchanging information outside the classroom boundaries and creating students' personal learning environments. With this kind of environment, students choose how to learn and what to learn. This causes a transformation in students' thinking because of promoting creativity, collaboration and communication. This mode of learning corresponds with the Connectivism theory which cares about the learning environment, and understanding the learning process. It focuses on opinions' diversity, learning which happened outside the people, the connections between information, students' ability for decision-making, and 
up-to-date knowledge. In the light of the variety of web 2.0 tools, the focus of the current study is on blogs and Google Docs, because of its characteristics which allows collaborating and controlling at the same time.

From the research review, the researcher found that both tools (blogs, and Google docs) were effective tools for educational purposes. All of them also enabled receiving peer feedback and teacher feedback. Both of them gave the learners a chance to collaborate. To use these tools, students needed to have interest and skills to use a computer. The ability to get accessto the internet was a challenge for some students. This problem could be overcome by allowing students to use the university's computer labs. In using blogs, limited general English proficiency hindered students' blogging (Lin, et al., 2013). This was because of the public audience of an internet blog. But the researcher thought that this should motivate students to develop their using of language. In Google docs, the spell and grammar check features provided learners with automatic feedback. But a periodic missing data from the screen was one of the problems facing the students while using Google docs. This problem could be resolved through publishing students' works on the blog like Sofia's study.

\section{Research Design}

The researcher adopted the descriptive methodology. Participants in the current study were:

1- $\quad$ Eight female instructors from ELC at Taif University who had taught intensive English language courses responded to the questionnaire. It was a purposeful sample.

2- $\quad$ Twenty female students from ELC at Taif University who joined to pre-intermediate level in intensive language courses in the third session of the second semester of 1436/ 1437 and attended to the classroom on the day of application were the participants in this study.

Research material consisted of a proposed model based on using web 2.0 for developing female students' English writing skills. The researcher used Gerlach and Ely model for designing the current proposed model. Branch \& Gustafson (2002) mentioned that the "Gerlach and Ely model (1980) is a mix of linear and concurrent development activities." P.19. Figure (1) showed Gerlach and Ely model. 
Figure (1): Gerlach and Ely Model. (Gerlach and Ely, 1980) cited in (Grabowski and Branch, 2003)

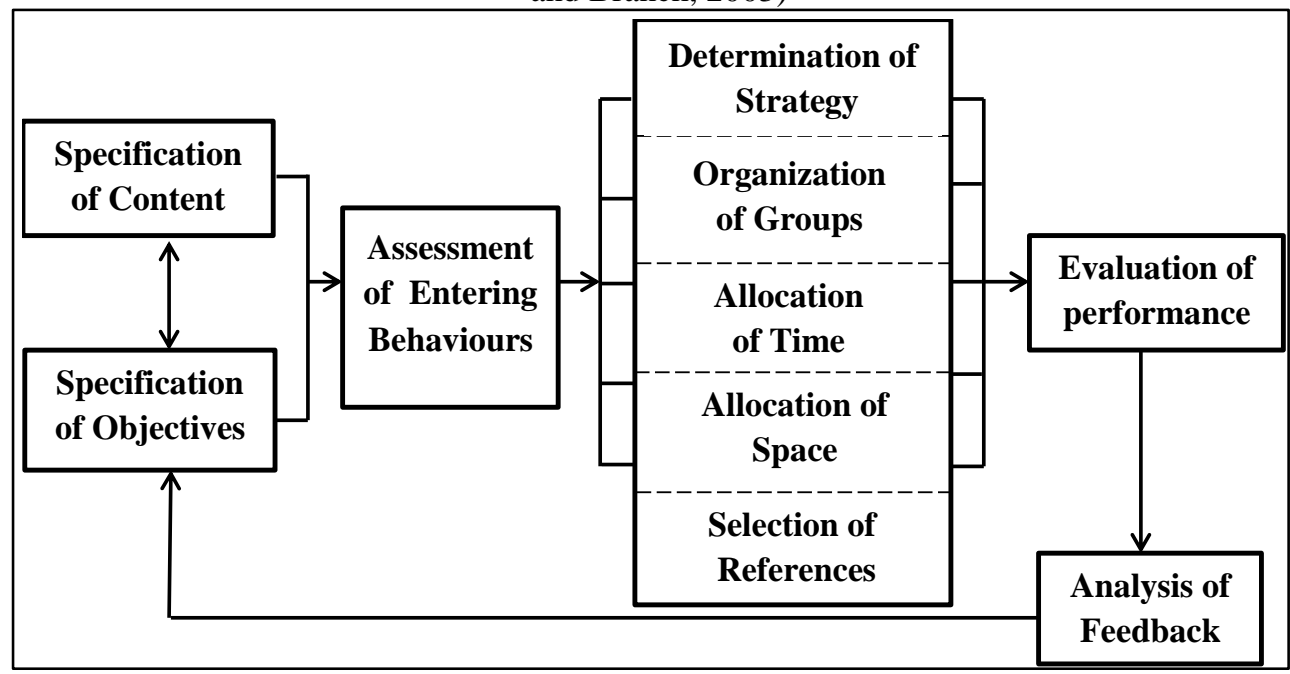

\section{Model's aims}

This model aims to:

1- $\quad$ Provide a blended learning environment for learning writing skills.

2- $\quad$ Encourage students' interaction in the learning process.

3- $\quad$ Replace the traditional teaching instruments with modern teaching instruments.

4- Enhance self-learning and collaborative learning values among students.

5- $\quad$ Train students on writing for the audience.

\section{Model's Tools}

In this model, two Web2.0 tools will be used: blog and Google Docs. 


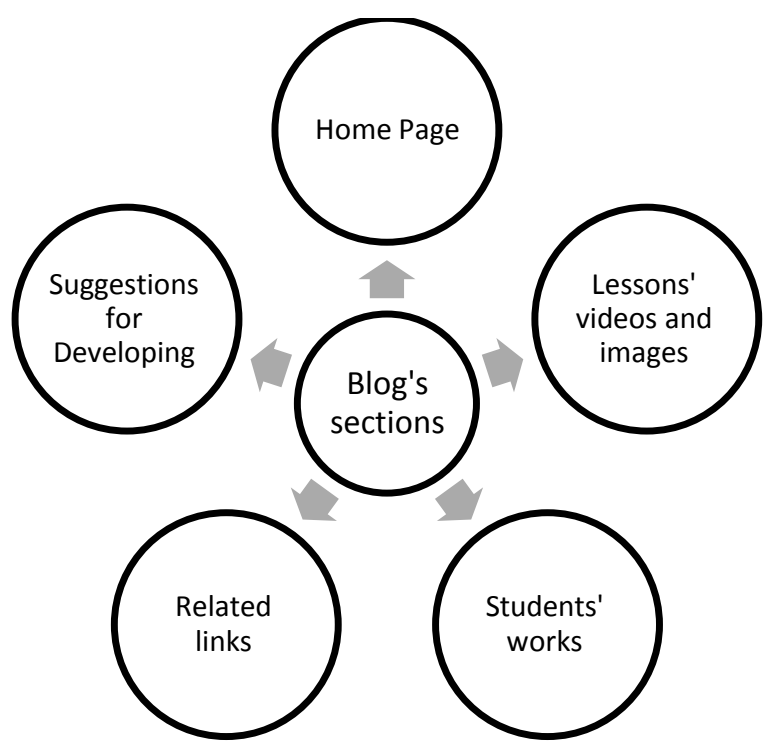

Figure (2): Blog's sections

\section{Blog's Design}

This blog will have 7 sections:

1- $\quad$ Home Page: The instructor will show course objectives and present overview about the content of the other sections. It will also contain the criteria of assessment.

2- $\quad$ Lessons' videos and images: Videos to explain the lessons will be presented. The existed videos on YouTube will be used in this model. Some lessons will be presented through pictures.

3- $\quad$ Students' works: The instructor will display students' final draft of every work. The instructor can display all students' work or the distinguishable ones.

4- $\quad$ Related links: It will contain additional links related to the lessons.

5- $\quad$ Suggestions for Developing: It will tend to develop the blog, the assignments, teaching methods and strategies and so on through visitors' suggestions. Visitors may be from students or others.

\section{Google Docs}

Google Document will be used for doing assignments. While doing assignments, students can receive peer feedback and teacher feedback. Assignments can be done individually or in small groups. 


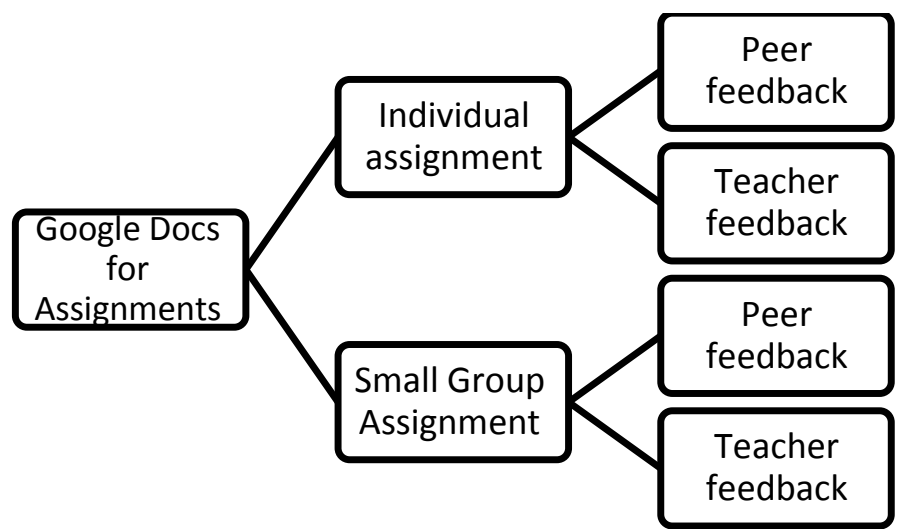

Figure (3) Google Docs for Assignments

\section{Model's Components}

\section{Specification of Course content:}

Course content will combine the selected images, videos on YouTube and the textbook content on New Headway Plus, special edition, preintermediate workbook. Table (1) shows course content related to writing skill from New Headway Plus, pre-intermediate workbook and lesson's videos and images.

Table (1): course content

\begin{tabular}{|c|c|c|}
\hline Unit & Writing skill development & Lessons' videos and images \\
\hline $\begin{array}{l}\text { 1-Getting to } \\
\text { know you. }\end{array}$ & $\begin{array}{l}\text { Informal letters } \\
\text { A letter to a penfriend } \mathrm{WB} p 9\end{array}$ & $\begin{array}{l}\text { https://youtu.be/RETHx9MIWOA } \\
\text { https://youtu.be/ 8I2Y-i7Qq4 }\end{array}$ \\
\hline $\begin{array}{l}\text { 2-The way } \\
\text { we live. }\end{array}$ & $\begin{array}{c}\text { Linking words } \\
\text { But, however, so, because, although } \\
\text { WB p14 } \\
\text { Describing a person WB p15 }\end{array}$ & $\begin{array}{c}\text { https://youtu.be/04RXXkgyfGQ } \\
\text { https://goo.gl/81nJxY } \\
\text { http://goo.gl/1T1QZa } \\
\text { http://goo.gl/mwlPiA }\end{array}$ \\
\hline $\begin{array}{l}\text { 3-It all went } \\
\text { wrong. }\end{array}$ & $\begin{array}{l}\text { Writing a narrative-linking words } \\
\text { While, during, and for WB p20 } \\
\text { Writing a story } 1 \text { WB p21 }\end{array}$ & $\begin{array}{l}\frac{\text { https://youtu.be/bwXw-9nk71E }}{\text { https://youtu.be/jUbVH20qW0A }} \\
\frac{\text { https://youtu.be/2hqwANBcOJM }}{\text { https://youtu.be/lPX XUVxLFQ }} \\
\underline{\text { http://goo.gl/OokqgG }}\end{array}$ \\
\hline $\begin{array}{l}\text { 4-Let's go } \\
\text { shopping! }\end{array}$ & Filling in forms WB p26 & Scanning WB p26 \\
\hline $\begin{array}{c}5 \text {-What do } \\
\text { you want to } \\
\text { do? }\end{array}$ & Writing a postcard WB p32 & $\begin{array}{l}\text { https://youtu.be/IP2BrsaQzvY } \\
\text { https://youtu.be/a3f-wGdVLA0 }\end{array}$ \\
\hline $\begin{array}{l}\text { 6-Tell me! } \\
\text { What's it } \\
\text { like? }\end{array}$ & $\begin{array}{c}\text { Relative clauses 1 } \\
\text { Who/that/which/where WB p37 } \\
\text { Describing a place WB p37 }\end{array}$ & $\begin{array}{c}\text { https://youtu.be/lRueqXUrYZM } \\
\text { https://youtu.be/REqHBWShZxI?t=8s }\end{array}$ \\
\hline 7-Fame. & $\begin{array}{c}\text { Relative clauses } 2 \\
\text { Who/ which/ that as the object WB } \\
\text { p41 } \\
\text { Writing a biography WB p42 }\end{array}$ & $\begin{array}{l}\frac{\text { https://youtu.be/EC7oeUTVVnQ }}{\text { http://goo.gl/HrNZA0 }} \\
\underline{\text { https://youtu.be/V2oJ6PND0TI }}\end{array}$ \\
\hline 8-Do's and & Writing letters & https://youtu.be/kenEvdqCrL8 \\
\hline
\end{tabular}




\begin{tabular}{|c|c|c|}
\hline Unit & Writing skill development & Lessons' videos and images \\
\hline Don'ts & Formal letters WB p47 & https://youtu.be/dvfKm2DAgKg \\
\hline $\begin{array}{l}\text { 9-Going } \\
\text { places. }\end{array}$ & $\begin{array}{c}\text { Linking words } 2 \\
\text { Discussing ideas: Advantages and } \\
\text { disadvantages WB p52 } \\
\end{array}$ & https://youtu.be/EHOnGf5FPb0 \\
\hline $\begin{array}{l}\text { 10-Scared to } \\
\text { death. }\end{array}$ & $\begin{array}{c}\text { Writing letters } \\
\text { Formal and informal letters 1WB } \\
\text { p57 }\end{array}$ & https://youtu.be/PgwmAUJx248 \\
\hline $\begin{array}{l}\text { 11-Things } \\
\text { that changed } \\
\text { the world. }\end{array}$ & $\begin{array}{c}\text { Writing an email- Linking words } 2 \\
\text { but,although, however, so, and } \\
\text { because WB p63 }\end{array}$ & $\frac{\underline{\text { https://youtu.be/BBLCQX4H4kQ }}}{\text { https://youtu.be/WIp4eOuV848 }}$ \\
\hline $\begin{array}{l}\text { 12-Dreams } \\
\text { and reality. }\end{array}$ & $\begin{array}{c}\text { Adverbs WB p68 } \\
\text { Writing a story } 2 \text { WB p68 }\end{array}$ & $\begin{array}{l}\underline{\text { https://youtu.be/bwXw-9nk71E }} \\
\text { https://youtu.be/jUbVH20qW0A } \\
\text { https://youtu.be/2hqwANBcOJM } \\
\text { https://youtu.be/lPX XUVxLFQ }\end{array}$ \\
\hline $\begin{array}{l}\text { 13-Earning a } \\
\text { living. }\end{array}$ & $\begin{array}{c}\text { Writing letters } \\
\text { Expressions in different kinds of } \\
\text { letters } 2 \mathrm{WB} \text { p74 } \\
\text { Formal and informal emails } 2 \mathrm{WB} \\
\text { p75 }\end{array}$ & $\begin{array}{l}\text { https://youtu.be/BBLCQx4H4kQ } \\
\underline{\text { https://youtu.be/WIp4eOuV848 }} \\
\text { https://youtu.be/PgwmAUJx248 }\end{array}$ \\
\hline $\begin{array}{l}\text { 14-Family } \\
\text { ties. }\end{array}$ & Writing for talking WB p80 & Scanning WB p80 \\
\hline
\end{tabular}

\section{Specification of Course Objectives}

1- Write an informal letter.

2- $\quad$ Use linking words such as"but, however, so, because, and, although".

3- Use a narrative-linking words (while, during, for).

4- Write a paragraph to describe a person.

5- Write a story.

6- $\quad$ Fill in forms.

7- Write a postcard.

8- Make relative clauses using "who, that, which, where" to join sentences.

9- $\quad$ Write a paragraph to describe a place.

10-Write a biography.

11-Use relative pronouns as a subject or as an object.

12-Write a formal letter.

13-Discuss ideas through writing.

14-Write formal and informal email.

15-Use adverbs correctly.

16-Recognize expressions in informal and formal letter writing.

17-Write a talk about future plans and dreams. 


\section{Assessment of Entering Behaviour}

A- Students should pass English level test.

B- Students and instructors should have skills in using computers in general and blogging skills in particular.

C- Students and instructors should have a Gmail account.

\section{Allocation of Time/ 5- Determination of strategy/6- Organization of} Groups/ 7-Allocation of Space:

\begin{tabular}{|c|c|c|c|c|}
\hline $\begin{array}{c}\text { Phases } \\
\text { "allocation of } \\
\text { time" }\end{array}$ & $\begin{array}{c}\text { Students' and } \\
\text { instructor's role }\end{array}$ & $\begin{array}{c}\text { Teaching and learning } \\
\text { strategies "Determination } \\
\text { of strategy" }\end{array}$ & $\begin{array}{l}\text { Model's } \\
\text { tools } \\
\text { "allocation } \\
\text { of space" }\end{array}$ & $\begin{array}{l}\text { Organizati } \\
\text { on of group }\end{array}$ \\
\hline $\begin{array}{l}\text { Phase (1): } \\
\text { Preparing the } \\
\text { lesson. }\end{array}$ & $\begin{array}{l}\text { 1- The instructor will } \\
\text { choose the appropriate } \\
\text { videos or images for the } \\
\text { lesson. } \\
\text { 2- The instructor will post } \\
\text { the videos or images in } \\
\text { the section of the lesson's } \\
\text { video and images. }\end{array}$ & & On the blog. & \\
\hline \multirow[t]{2}{*}{$\begin{array}{l}\text { Phase (2): } \\
\text { Getting the } \\
\text { lesson. }\end{array}$} & $\begin{array}{l}\text { 1- Students will get the } \\
\text { lesson through video or } \\
\text { images. }\end{array}$ & $\begin{array}{l}\text { The note - making strategy } \\
\text { will be used to extract and } \\
\text { record the main ideas in an } \\
\text { organized and systematic } \\
\text { way. }\end{array}$ & $\begin{array}{l}\text { Using the } \\
\text { blog. }\end{array}$ & $\begin{array}{l}\text { Individual } \\
\text { activity. }\end{array}$ \\
\hline & $\begin{array}{l}\text { 2- Students discuss the } \\
\text { lesson's issues with the } \\
\text { instructor and their } \\
\text { colleagues and may do } \\
\text { some exercises. }\end{array}$ & & $\begin{array}{l}\text { In the } \\
\text { classroom }\end{array}$ & $\begin{array}{l}\text { Whole-class } \\
\text { activity. }\end{array}$ \\
\hline \multirow[t]{3}{*}{$\begin{array}{l}\text { Phase (3): } \\
\text { Getting the } \\
\text { assignment }\end{array}$} & $\begin{array}{l}\text { 1- Students get an } \\
\text { assignment and discuss it } \\
\text { together and with their } \\
\text { instructor. }\end{array}$ & $\begin{array}{l}\text { Brainstorming, graphic } \\
\text { organizers, planning sheets, } \\
\text { and concept maps could be } \\
\text { used in this step. }\end{array}$ & $\begin{array}{l}\text { In the } \\
\text { classroom }\end{array}$ & $\begin{array}{l}\text { Whole-class } \\
\text { activity. }\end{array}$ \\
\hline & $\begin{array}{l}\text { 2- Students will do the } \\
\text { assignment. }\end{array}$ & $\begin{array}{l}\text { The instructor can use any } \\
\text { of the following strategies: } \\
\text { scaffolded instruction, self- } \\
\text { regulated strategy } \\
\text { development (SRSD), the } \\
\text { POWER strategy, modelled } \\
\text { writing, , guided writing, } \\
\text { independent writing, } \\
\text { writing conferences, and } \\
\text { cooperative learning. }\end{array}$ & $\begin{array}{l}\text { Using } \\
\text { Google } \\
\text { Docs. }\end{array}$ & $\begin{array}{l}\text { Individually } \\
\text { or in small } \\
\text { group } \\
\text { activity. }\end{array}$ \\
\hline & $\begin{array}{l}\text { 3- Students will receive } \\
\text { peer feedback and teacher } \\
\text { feedback. } \\
\text { 4- Students will correct } \\
\text { their mistakes and } \\
\text { producing the final draft. }\end{array}$ & & $\begin{array}{l}\text { Using } \\
\text { Google } \\
\text { Docs. }\end{array}$ & \\
\hline $\begin{array}{l}\text { Phase (4): } \\
\text { Publishing. }\end{array}$ & $\begin{array}{l}\text { 1- The final draft will be } \\
\text { published in students' } \\
\text { work section. }\end{array}$ & & $\begin{array}{l}\text { Using the } \\
\text { blog. }\end{array}$ & \\
\hline
\end{tabular}




\section{Selection of Resources}

Workbook and blog posts will be learning resources in this model.

\section{Evaluation of performance}

Students' achievement will be measured by doing assignments from the workbook. The researcher built the following writing assessment rating scales to be the assessment tool in the model.

\begin{tabular}{|c|c|c|c|c|c|c|}
\hline Category & Criterion & 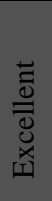 & $\begin{array}{l}\overline{8} \\
8 \\
00 \\
\overrightarrow{0} \\
>\end{array}$ & \begin{tabular}{l} 
Zृ \\
\hdashline \\
\hdashline
\end{tabular} & $\begin{array}{l}\frac{0}{0} \\
\frac{\pi}{0} \\
\frac{0}{0} \\
\frac{0}{4}\end{array}$ & $\frac{y}{\text { है }}$ \\
\hline \multirow[t]{2}{*}{ Capitalization } & $\begin{array}{l}\text { Capitalize necessary letters in the middle of the } \\
\text { sentence. }\end{array}$ & & & & & \\
\hline & Capitalize the first letter in each sentence. & & & & & \\
\hline \multirow[t]{8}{*}{ Grammar } & Use the correct verb tense. & & & & & \\
\hline & Use subject-verb agreement. & & & & & \\
\hline & Avoid fragments in writing sentences. & & & & & \\
\hline & Use negation forms correctly. & & & & & \\
\hline & Write an appropriate sentence structure. & & & & & \\
\hline & Write a correct question form. & & & & & \\
\hline & Use suffixes correctly. & & & & & \\
\hline & Use prefixes correctly. & & & & & \\
\hline \multirow[t]{2}{*}{ Article } & Use definite article correctly. & & & & & \\
\hline & Use indefinite article in the right way. & & & & & \\
\hline \multirow[t]{4}{*}{ Spelling } & Spell the words correctly. & & & & & \\
\hline & Spell the irregular verbs correctly. & & & & & \\
\hline & Spell the verb correctly when adding [s],[ed],[ing]. & & & & & \\
\hline & Use the correct plural forms of nouns. & & & & & \\
\hline \multirow[t]{3}{*}{ Pronouns } & Use the correct pronouns. & & & & & \\
\hline & Use relative pronouns to express subject correctly. & & & & & \\
\hline & Use relative pronouns to express objective correctly. & & & & & \\
\hline \multirow[t]{2}{*}{ Prepositions } & Use the proper prepositions. & & & & & \\
\hline & Omit the unnecessary prepositions. & & & & & \\
\hline \multirow{6}{*}{$\begin{array}{l}\text { Discourse and } \\
\text { pragmatic } \\
\text { aspects }\end{array}$} & Choose appropriate vocabulary. & & & & & \\
\hline & Use appropriate punctuation marks in the right places. & & & & & \\
\hline & Avoid redundancy. & & & & & \\
\hline & Give relevant ideas to the topic. & & & & & \\
\hline & $\begin{array}{l}\text { Produce clear and concise sentences that convey a } \\
\text { specific meaning. }\end{array}$ & & & & & \\
\hline & Organize the ideas properly. & & & & & \\
\hline
\end{tabular}

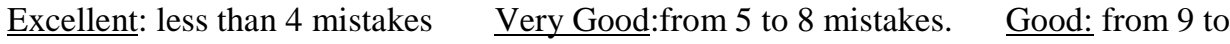

12mistakes. Acceptable: from 13 to 16 mistakes. Weak: more than 16 mistakes.

\section{Analysis of feedback}

Students will give suggestions and feedback about teaching procedures and course content. They will use the section of suggestion for developing on the blog to give feedback. 


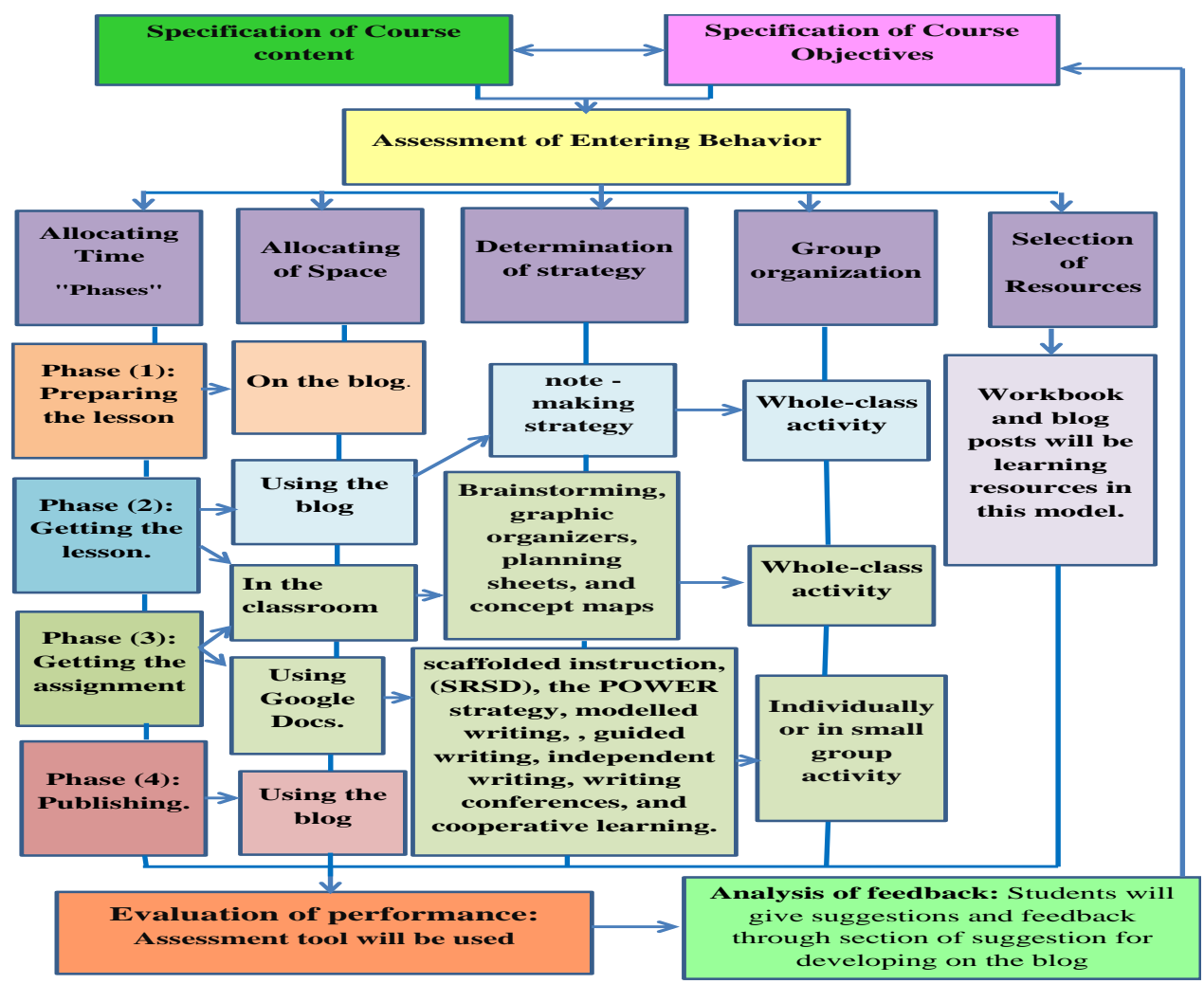

Figure (4): The proposed model based on using web 2.0 for developing English writing skills

\section{Research Instruments}

Instructors' questionnaire and students' questionnaire used to explore their acceptance level of the proposed model. The researcher adapted the Technology Acceptance Model (TAM) to explore the acceptance level of the proposed model because the current proposed model depended on using technology for teaching and learning. The researcher adapted TAM from three studies: (Davis, 1989), (Venkatesh and Davis, 2000) and (Lee et al., 2011).

Both questionnaires were validated by specialists in English language curricula and teaching method and educational technology. Six specialists validated instructors' questionnaire and seven specialists validated the students' questionnaire. Most of the items were modified linguistically. One of the specialists suggested changing the linguistic form of variable of computer self-efficacy to self-efficacy with the proposed model. Three items were deleted from instructors' questionnaire and two from the students' questionnaire. 
After modifying both questionnaires according to specialists' suggestions, 40 items of the instructors' questionnaire and 33 items of the students' questionnaire were ready for testing reliability. Sample of five female instructors and ten female students responded to the instructors' questionnaire and the students' questionnaire respectively. Reliability test was conducted by using Cronbach's Alpha. The overall reliability results were 0.877 for an instructors' questionnaire and 0.913 for students' questionnaire. Reliability coefficient is preferred to be more than 0.80 when measurements address attitudes (Abu Allam, 2011). So, they were reliable. The final drafts of Instructors' questionnaire and students' questionnaire items showed as follows:

Table (2): Instructors' Questionnaire Items

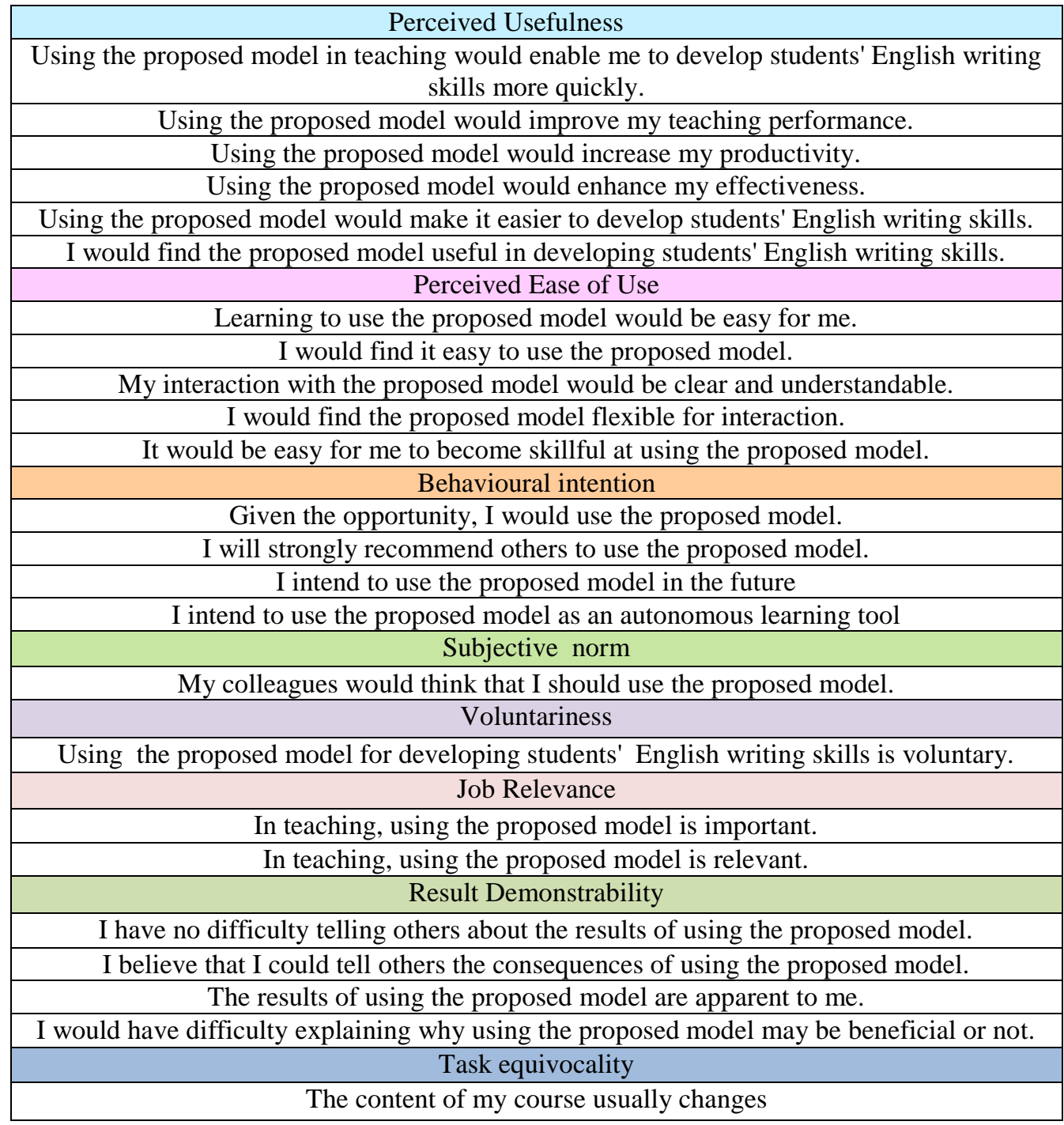




\begin{tabular}{|c|}
\hline I usually have to adopt different methods or procedures to teach my students \\
\hline Individuals' experience with computers \\
\hline I have no enjoyment in using computers \\
\hline Working with a computer would make me very nervous \\
\hline I have a fear when I think of trying to use a computer \\
\hline Using computers may make me feel uneasy and confused \\
\hline Self-efficacy with the proposed model \\
\hline $\begin{array}{l}\text { I am confident of using the proposed model; even if I have only the model manuals for } \\
\text { reference }\end{array}$ \\
\hline I am confident of using the proposed model; even if I have never used such a model before. \\
\hline $\begin{array}{c}\text { I am confident of using the proposed model; as long as I have just seen someone using it } \\
\text { before trying it myself }\end{array}$ \\
\hline $\begin{array}{l}\text { I am confident of using the proposed model; as long as I have a lot of time to complete the } \\
\text { job for which the model is provided }\end{array}$ \\
\hline I am confident of using the proposed model; as long as someone shows me how to do it \\
\hline Management support \\
\hline $\begin{array}{l}\text { I am always supported and encouraged by my boss to use technology to develop students' } \\
\text { English writing skills. }\end{array}$ \\
\hline My boss has a high interest that I use technology to develop students' English writing skills \\
\hline $\begin{array}{l}\text { I am always supported and encouraged by my administrators to use technology to to } \\
\text { develop students' English writing skills }\end{array}$ \\
\hline Organizational support \\
\hline It is important for me to encourage the use of the proposed model within the organization \\
\hline $\begin{array}{c}\text { It is important for me to provide useful resources for the proposed model within the } \\
\text { organization }\end{array}$ \\
\hline $\begin{array}{c}\text { When I use the proposed model the provision of technical support assistance from the } \\
\text { organization is very important. }\end{array}$ \\
\hline
\end{tabular}

Note. All items were measured on a 5-point Likert scale, where 1 _ strongly disagree, 2 disagree, $3_{\text {_ }}$ neutral (neither disagree nor agree), $4_{\text {_ }}$ agree, 5 _ strongly agree.

Table (3): Students' Questionnaire Items

\begin{tabular}{|c|}
\hline $\begin{array}{c}\text { Perceived Usefulness } \\
\text { Using the proposed model in learning would enable me to develop my English writing skills } \\
\text { more quickly. }\end{array}$ \\
\hline Using the proposed model would improve my learning outcomes . \\
\hline Using the proposed model would increase my productivity. \\
Using the proposed model would enhance effectiveness. \\
\hline Using the proposed model would make it easier to develop my English writing skills. \\
\hline I would find the proposed model useful in developing my English writing skills. \\
\hline Perceived Ease of Use \\
\hline The proposed model is easy to use. \\
\hline My interaction with the proposed model would be clear and understandable. \\
\hline I would find the proposed model to be flexible to interact with. \\
\hline It would be easy for me to become skillful at using the proposed model. \\
\hline Behavioural intention \\
\hline Given the opportunity, I would use the proposed model \\
\hline
\end{tabular}




\begin{tabular}{|c|}
\hline I will strongly recommend others to use the proposed model. \\
\hline I intend to use the proposed model in the future \\
\hline I intend to use the proposed model as an autonomous learning tool \\
\hline Subjective norm \\
\hline My colleagues would think that I should use the proposed model \\
\hline Job Relevance \\
\hline In learning, using the proposed model is important. \\
\hline In learning, using the proposed model is relevant. \\
\hline Result Demonstrability \\
\hline I have no difficulty telling others about the results of using the proposed model. \\
\hline I believe that I could tell others the consequences of using the proposed model. \\
\hline The results of using the proposed model are apparent to me. \\
\hline I would have difficulty explaining why using the proposed model may be beneficial or not. \\
\hline Individuals' experience with computers \\
\hline I have no enjoyment in using computers \\
\hline Working with a computer would make me very nervous \\
\hline I have a fear when I think of trying to use a computer \\
\hline Using computers may make me feel uneasy and confused \\
\hline Self-efficacy with the proposed model \\
\hline $\begin{array}{l}\text { I am confident of using the proposed model; even if I have only the model manuals for } \\
\text { reference }\end{array}$ \\
\hline I am confident of using the proposed model; even if I have never used such a model before \\
\hline $\begin{array}{c}\text { I am confident of using the proposed model; as long as I have just seen someone using it } \\
\text { before trying it myself }\end{array}$ \\
\hline $\begin{array}{l}\text { I am confident of using the proposed model; as long as I have a lot of time to complete the } \\
\text { job for which the model is provided }\end{array}$ \\
\hline I am confident of using the proposed model; as long as someone shows me how to do it \\
\hline Instructor support \\
\hline $\begin{array}{c}\text { My instructor always supports and encourages me to use technology for developing my } \\
\text { English writing skills }\end{array}$ \\
\hline $\begin{array}{c}\text { My instructor has a high interest in using technology for developing my English writing } \\
\text { skills }\end{array}$ \\
\hline
\end{tabular}

Note. All items were measured on a 5-point Likert scale, where $1_{-}$strongly disagree, $2_{-}$

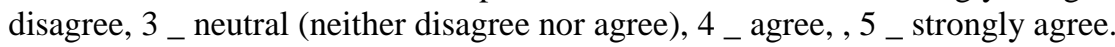

\section{Research Procedures}

To collect the research data, the following procedures were followed: 1. Getting permission to apply the research instruments.

2. Applying the research instruments through explaining the proposed model for the participants. The presentation included model's aims, and model's tools. The way of applying the model was explained, then the participants were asked to fill the questionnaires.

3. Preparing the quantitative data for analysis:

a- $\quad$ Score the data. (Such as $5=$ strongly agree, $4=$ agree, $3=$ neutral, $2=$ disagree, and $1=$ strongly disagree.) 
b- $\quad$ Determine the type of the scores. The single - item score was used in the current study. "A single-item score is an individual score assigned to each question for each participant in [the] study" (Creswell, 2012: 177).

c- $\quad$ Select SPSS to analyse the data.

d- Input the data.

e- $\quad$ Eliminate participants with missing scores from the data analysis.

f- Conduct descriptive statics choosing mean.

\section{Results}

For the quantitative analysis, the weighted mean was calculated to identify the level of agreement (Abdul-Fattah, 2013). Three steps were done:

1- To identify the length of the cells in fifth Likert scale, the range was computed. (The largest value in the scale - The smallest value in the scale $=$ Range $)(5-1=4)$.

2 - Then, the range is divided by the largest value in the scale to have the length of the cell $(4 \div 5=0.80)$.

3- After that, the value was added to the smallest value in the scale (1) to identify the maximum of the cell. The length of the cells became as the following:

Table (4): Level of agreement and weighted mean

\begin{tabular}{|c|c|}
\hline Level of Agreement & Weighted Mean Value \\
\hline Strongly disagree & $1-1.79$ \\
\hline Disagree & $1.80-2.59$ \\
\hline Neutral & $2.60-3.39$ \\
\hline Agree & $3.40-4.19$ \\
\hline Strongly agree & $4.20-5.00$ \\
\hline
\end{tabular}

The study results represented in two fields as the following:

\section{A. Students' acceptance level of the proposed model:}

Table (5): Total mean of students' respondents for all variables in general

\begin{tabular}{|c|c|c|c|}
\hline Variables & Mean & Std. Deviation & Level of Agreement \\
\hline Perceived Usefulness & 4.1667 & .47140 & Agree \\
\hline Perceived Ease of Use & 3.8000 & .72548 & Agree \\
\hline Behavioural Intention & 4.1500 & .47573 & Agree \\
\hline Subjective Norm & 3.2000 & .89443 & Neutral \\
\hline Job Relevance & 3.9250 & .71221 & Agree \\
\hline Result Demonstrability & 3.5500 & .62618 & Agree \\
\hline $\begin{array}{c}\text { Individuals' Experience with } \\
\text { Computer }\end{array}$ & 2.3750 & .93365 & Aisagree \\
\hline $\begin{array}{c}\text { Self-Efficacy with the Proposed } \\
\text { Model }\end{array}$ & 3.9300 & .48243 & Neutral \\
\hline Instructor Support & 3.2500 & .85070 & Agree \\
\hline Total Mean & 3.5941 & .38285 & \\
\hline
\end{tabular}


Table (5) showed that students agreed with the variables of perceived usefulness, perceived ease of use, behavioural intention, job relevance, result demonstrability, and self-efficacy with the proposed model. But they were neutral about subjective norm and instructor support. Also, they disagreed with the negative statements of individuals' experience with computers.

To sum up, the total mean of all the variables in general was 3,59 which meant that students had positive attitudes toward the proposed model. So, students who participated in the current study accepted the proposed model.

\section{B. Instructors' acceptance level of the proposed model:}

Table (6): Total mean of instructors' respondents for all variables in general

\begin{tabular}{|c|c|c|c|}
\hline Variables & Mean & Std. Deviation & Level of Agreeement \\
\hline Perceived Usefulness & 3.8958 & .60381 & Agree \\
\hline Perceived Ease of Use & 3.7000 & .74833 & Agree \\
\hline Behavioural Intention & 3.6250 & .56695 & Agree \\
\hline Subjective Norm & 3.2500 & 1.16496 & Neutral \\
\hline Voluntariness & 3.1250 & 1.12599 & Neutral \\
\hline Job Relevance & 3.7500 & .92582 & Agree \\
\hline Result Demonstrability & 3.8750 & .80178 & Agree \\
\hline Task Equivocality & 3.5625 & .56300 & Atrongly Disagree \\
\hline $\begin{array}{c}\text { Individuals' Experience with } \\
\text { Computer }\end{array}$ & 1.3750 & .42258 & Agree \\
\hline $\begin{array}{c}\text { Self-Efficacy with the Proposed } \\
\text { Model }\end{array}$ & 3.6500 & .70711 & Strongly Agree \\
\hline Management Support & 4.2083 & .64087 & Agree \\
\hline Organizational Support & 4.0417 & .88079 & Agree \\
\hline Total Mean & 3.5049 & .53120 & \\
\hline
\end{tabular}

Table (6) showed that instructors strongly agreed with the management support variable. They also agreed with perceived usefulness, perceived ease of use, behavioural intention, job relevance, task equivocality, result demonstrability, self-efficacy with the proposed model, and organizational support. However, they were neutral about subjective norm and voluntariness. They strongly disagreed with the negative statements of individuals' experience with computers.

To sum up, the total mean of all the variables in general was 3,50 which meant that instructors had positive attitudes toward the proposed model. So, instructors who participated in the current study accepted the proposed model.

\section{Results Discussion}

Instructors and students showed positive attitudes toward usefulness of the proposed model. They thought that the proposed model may improve 
their outcomes and productivity and enhance their effectiveness. They agreed that it may develop English writing skills easily and quickly. These results corresponded to the results of the previous studies which proved that either blog or Google Docs were effective tools to develop English writing skills (Edwards, 2011; Hedin, 2012; Krajka, 2012; Aydin, 2014; Arslan, 2014; Ting, 2015).

Both of them agreed with the variable of perceived ease of use. The results showed that the proposed model would be easy to learn and to use. By using the proposed model, instructors' and the students' interaction would be clear, understandable and flexible. They were motivated to become skillful at using the proposed model. Suwantarathip and Wichadee (2014) found that students perceived that Google Docs was easy to use as learning tool. This agreed partially with the current study.

In addition, both students and instructors would intend to use the proposed model if they had the opportunity and encourage others to use it. But they neither agreed nor disagreed with the variable of subjective norm. They may not care about the colleagues' impression when they use the proposed model or not. Similarly, instructors were neutral toward voluntariness of using the proposed model.

In job relevance variable, both students and instructors agreed with all statements. So, the proposed model could be important and relevance in teaching and learning process. This agreement reflected their awareness of how important is to use technology in the educational field. They knew that using technology and especially the proposed model may make their tasks more easily.

Lin, et al. (2013) found that students had feelings of anxiety and embarrassment; however, both students and instructors in the current study accepted to demonstrate the results of using the proposed model to others. They also could expect the results of using the proposed model. But they hesitate to explain the reason behind if using the proposed model would be beneficial or not. This may refer to their needs to try the proposed model to know the results.

In instructors' task equivocality, using the proposed model would not be affected passively by changing the course content. Their adaptation of different teaching methods helped them to accept the proposed model.

According to individuals' experience with computer, students' and instructors' levels of agreement were disagreeing and strongly disagreeing respectively. Although this result showed positive attitudes because the statements were negative, it may show that instructors were more positive than students because of the courses and workshops that they had in using technology. E-learning Deanship at the university produced these courses. 
Students in the current study had no problem if they did not use such the proposed model before. Both students and instructors wanted to have model manuals for reference, more time to use this model, and training on using the proposed model. Yunus et al. (2013) found that teachers' lack of time and students' lack of skills may deter students and teachers from using blogs for teaching writing.

In supporting, students were neutral about instructors' support. This may refer to the number of the instructors who teach them. On the other hand, instructors showed that they received high management support to use technology for teaching. They also received organizational support as their respondents, but they may need more.

\section{Conclusion}

With reference to the results of the study, Students and instructors in ELC who participated in the current study accepted the proposed model. If they have enough time and skills, they may use the proposed model. So, workshops could be conducted to help instructors and students to acquire the necessary skills. Participants needed more organizational support. The results of this study cannot be generalized because of the small purposeful sample. Based on the results, it is recommended to use technology in the intensive English language courses which were presented by the ELC. Further, some studies are suggested such as: investigate the effectiveness of the proposed model in the current study, and conduct other studies using other web 2.0 tools to develop English writing skills.

\section{References:}

1. Abdul-Fattah, E. (2013). Discovering Statistical Analysis And Bootstrap By Using IBM-SPSS. Jeddah: Khawarizm Academic. (Arabic reference)

2. Abu Allam, R. M. (2011). Research Methodologies In Psychological And Educational Science (7th ed.). Cairo: Darannashr. (Arabic reference)

3. Ahmed, O. N. (2012). The effect of different learning styles on developing writing skills of EFL Saudi learners. British Journal of Art and Social Sciences, 5(2), 220-233. [Available Online] Retrieved on October 9, 2015 from: http://www.bjournal.co.uk/paper/BJASS_5_2/BJASS_05_02_07.pdf

4. Al Fadda, H. (2012). Difficulties in academic writing: From the perspective of King Saud University postgraduate students. English Language Teaching, 5(3), 123. [Available Online] Retrieved on August 
http://www.ccsenet.org/journal/index.php/elt/article/viewFile/15272/ 10336

5. Ali, E., Jahin,J.\&Al-Shreef,M. (2013). Methods of Teaching English as a Foreign Language An Overview. Sakaka: Library of Babel.

6. Aljumah, F. H. (2012). Saudi learner perceptions and attitudes towards the use of blogs in teaching English writing course for EFL Majors at Qassim University. English Language Teaching, 5(1), 100. [Available online] Retrieved from http://files.eric.ed.gov/fulltext/EJ1079098.pdf

7. Al-Khairy, M. A. (2013). Saudi English-Major Undergraduates' Academic Writing Problems: A Taif University Perspective. English Language Teaching, 6(6), 1. [Available online] Retrieved from http://www.ccsenet.org/journal/index.php/elt/article/view/27256 .

8. Alqurashi, F. (2009). Saudi Students' Reactions to Peer Response Groups in EFL Composition Classrooms. Online Submission, 21, 5767. [Available Online] Retrieved on October 9, 2015 from: https://www.academia.edu/9111420/Saudi_students_reactions_to_pe er_response_groups_in_EFL_composition_classrooms

9. Al-Seghayer, K. S. (2014). The actuality, inefficiency, and needs of EFL teacher-preparation programs in Saudi Arabia. International Journal of Applied Linguistics and English Literature, 3(1), 143-151. [Available online] Retrieved Septemper 10,2015 from: http://www.journals.aiac.org.au/index.php/IJALEL/article/viewFile/1 $\underline{035 / 965}$

10. Arslan, R. S. (2014). Integrating feedback into prospective English Language Teachers' writing process via blogs and portfolios. TOJET: The Turkish Online Journal of Educational Technology, 13(1). [Available online]Retrieved from http://www.tojet.net/articles/v13i1/13112.pdf

11. Aydin, S. (2014). The Use of Blogs in Learning English as a Foreign Language. Online Submission, 4(1), 244-259. [Available online] Retrieved from http://files.eric.ed.gov/fulltext/ED545624.pdf

12. Bader, F. (2007). Writing Under the Competency-Based Approach: The Case of Second Year Middle Pupils. (Master Dissertation), Mentouri University, Constantine. [Available Online] Retrieved on August 24, 2016 from: http://bu.umc.edu.dz/theses/anglais/BAD968.pdf

13. Barber, D. B., Barber, W. D., Karner, N. F., \& Laur, D. M. (2006). A Tool Kit for Adult Basic Skills Educators. [Available Online] Retrieved on October 1, 2015 from: http://abspd.appstate.edu/sites/abspd.appstate.edu/files/Teaching_Wri ting_Tool_Kit.pdf 
14. Barkaoui, K. (2007). Teaching Writing to Second Language Learners: Insights from Theory and Research. TESL Reporter, 40(1), 35-48. [Available Online] Retrieved on August 24, 2016 from: https://journals.lib.byu.edu/spc/index.php/TESL/article/viewFile/323 $\underline{04 / 30503}$

15. Bayat, N. (2014). The Effect of the Process Writing Approach on Writing Success and Anxiety. Educational Sciences: Theory and Practice, 14(3), 1133-1141. [Available Online] Retrieved on August 24, 2016 from: http://files.eric.ed.gov/fulltext/EJ1034097.pdf

16. Branch, R., \& Gustafson, K. (2002). Survey of Instructional Development Models. Syracuse, NY: Clearinghouse on Information and Technology.(ERIC Document Reproduction Service No. 477517). [Available online] Retrieved February 27, 2016 from: http://files.eric.ed.gov/fulltext/ED477517.pdf

17. Brodahl, C., Hadjerrouit, S., \& Hansen, N. K. (2011). Collaborative Writing With Web 2.0 Technologies: Education Students' Perceptions. [Available online]Retrieved from https://brage.bibsys.no/xmlui//bitstream/handle/11250/138167/Broda hl_2011_Collaborative.pdf?sequence $=1$ \&isAllowed $=y$

18. Broughton, G., Brumfit, C., Pincas, A., \& Wilde, R. D. (2003). Teaching English as a Foreign Language: Routledge. [Available Online] Retrieved on October 3, 2015 from: http://elibrary.kiu.ac.ug:8080/jspui/bitstream/1/269/1/Teaching\%20E nglish\%20as\%20a\%20Foreign\%20Language\%20(Routledge\%20Edu cation\%20Books).pdf

19. Chinnery, G. M. (2008). External Links Valid at Time of Publication ON THE NET You've Got some GALL: Google-Assisted Language Learning. Language Learning \& Technology, 12(1), 3-11. [Available Online] Retrieved on September 27, 2015 from: http://llt.msu.edu/vol12num1/pdf/net.pdf

20. Creswell, J. (2012). Educational Research: Planning, Conducting, and Evaluating Quantitative and Qualitative Research.: Pearson, Boston, MA. [Available online] Retrieved February 23, 2016 from: https://www.google.com.sa/url?sa=t\&rct=j\&q=\&esrc=s\&source=web $\& \mathrm{~cd}=2 \& \mathrm{cad}=\mathrm{rja} \& u a c t=8 \& \mathrm{ved}=0$ ahUKEwiO4tWv5I_LAhXFPxoKH Qh3C4kQFggpMAE\&url=https\%3A\%2F\%2Feclass.uoa.gr\%2Fmodu les\%2Fdocument\%2Findex.php\%3Fcourse\%3DPPP630\%26downloa d\%3D\%2F5675d94bTYjI.pdf\&usg=AFQjCNF4GoBPWZtNVCddK KgBMYfgUfWsGg\&sig2=63K_SUK4RwhmafbNJLYgcg

21. Cummins, J. (2009). Supporting ESL Students in Learning the Language of Science. [Available Online] Retrieved on August 27, 2016 
from:https://assets.pearsonschool.com/asset_mgr/legacy/200728/Sci Aut0404585MonoCummins_844_1.pdf

22. Curtis, A. K. (2013). Writing 2.0: Using Google Docs as a Collaborative Writing Tool in the Elementary Classroom. (Master Project. ), Utah Valley University. [Available online]Retrieved from http://contentdm.uvu.edu/cdm/ref/collection/UVUTheses/id/609

23. Davis, F. D. (1989). Perceived Usefulness, Perceived Ease of Use, and User Acceptance of Information Technology. MIS quarterly, 319-340. [Available online] Retrieved March 24, 2016 from: http://iris.nyit.edu/ kkhoo/Spring2008/Topics/TAM/PercieveUsefuln ess_MIS.pdf

24. Edwards, J. T. (2011). A Case Study: Using Google Documents as a Collaborative Writing Tool in Undergraduate Courses. The Texas Speech Communication Journal Online. [Available online]Retrieved from: http://www.etsca.com/tscjonline/0911-google/

25. Farooq, M. S., Uzair-Ul-Hassan, M., \& Wahid, S. (2012). Opinion of second language learners about writing difficulties in English language. South Asian Studies, 27(1), 183. [Available online] Retrieved on August 27, 2016, from: http://search.proquest.com/openview/4ef210f1473500e12cc40b4ced1 706fc/1?pq-origsite $=$ gscholar

26. Ford, P., Camilleri, M., Leja, H., \& Sollars, V. (2007). Blogs: Web Journals in Language Education. European Centre for Modern Languages: Council of Europe. [Available online] Retrieved on July $22, \quad 2015$ from: http://archive.ecml.at/mtp2/publications/D1_Blogs_E_internet.pdf

27. Gann, D. A. (2014). Pedagogical Affordances Of Two Online Document Types. Language Teacher, 38(4), 31. [Available online] Retrieved July 16, 2016 from: http://jalt-publications.org/files/pdfarticle/38.1tlt_wired.pdf

28. Grabowski, S., \& Branch, R. (2003). Teaching \& Media: A Systematic Approach. 2. [Available online] Retrieved February 27, 2016 from: http://sarah.lodick.com/edit/edit6180/gerlach_ely.pdf

29. Graham, S., \& Perin, D. (2007). Writing Next-Effective Strategies To Improve Writing Of Adolescents In Middle And High Schools. [Available Online] Retrieved on August 27, 2016 from:http://dl.ueb.edu.vn/bitstream/1247/9990/1/Writing\%20Next\%2 0-\%20\%20strategies\%20to\%20improve\%20writing.pdf

30. Grosseck, G. (2009). To Use Or Not To Use Web 2.0 In Higher Education? Procedia-Social and Behavioral Sciences, 1(1), 478-482. [Available Online] Retrieved on September 18, 2015 from: http://ac.els-cdn.com/S1877042809000895/1-s2.0- 


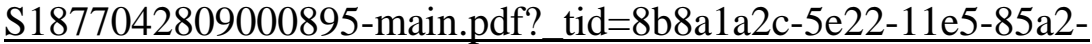

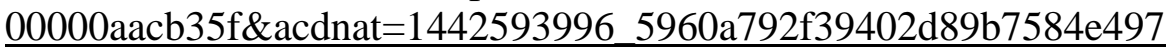
aefd62

31. Grosseck, G., \& Holotescu, C.(2008). Can We Use Twitter For Educational Activities. Paper presented at the 4th International Scientific Conference, Elearning And Software For Education, Bucharest, Romania. [Available Online] Retrieved on August 24, 2016 from: https://adlunap.ro/eLSE_publications/papers/2008/015.697.1.Grosseck\%20Gabriela-Can\%20we\%20use.pdf

32. Hedin, B. (2012). Peer Feedback in Academic Writing Using Google Docs. Paper presented at the LTHs 7: e Pedagogiska Inspirationskonferens.[Available online]Retrieved from: http://www.divaportal.org/smash/get/diva2:545205/FULLTEXT01.pdf

33. Huwari, I., \& Al-Khasawneh, F. (2013). The Reasons Behind The Weaknesses Of Writing In English Among Pre-Year Students' At Taibah University. English for Specific Purposes World, 38(14), 1-9. [Available Online] Retrieved on October 9, 2015 from: http://www.researchgate.net/profile/Ibrahim_Huwari/publication/236 231651_The Reasons_behind_the_Weaknesses_of_Writing_in_Engl ish_among_Pre-

year_Students'_at_Taibah_University/links/02e7e5173077c373ae000 000.pdf

34. Jahin, J. H., \& Idrees, M. (2012). Efl Major Student Teachers' Writing Proficiency And Attitudes Towards Learning English. Umm Al-Qura University Journal of Educational \& Psychologic Sciences, 4(1), 10-72. [Available Online] Retrieved on October 9, 2015 from: https://uqu.edu.sa/files2/tiny mce/plugins/filemanager/files/4280212/ TR4-1-10.pdf

35. Javid, C., \& Umer, M. (2014). Saudi EFL Learners' Writing Problems: A Move Towards Solution. Proceeding of the Global Summit on Education GSE, 4-5. [Available online]Retrieved from http://worldconferences.net/proceedings/gse2014/toc/papers_gse2014 /G\%20078\%20-

\%20CHOUNDHARY\%20ZAHID\%20JAVID_Saudi\%20EFL\%20Le arners_\%20Writing\%20Problems\%20A\%20Move\%20towards\%20S olution_read.pdf

36. Kieslinger, B., Grodecka, K., \& Wild, F. (2008). How To Use Social Software In Higher Education. [Available Online] Retrieved on September 27, 2015 from: http://www.icamp.eu/wpcontent/uploads/2009/01/icamp-handbook-web.pdf 
37. Kirby, D. L., \& Crovitz, D. (2013). Inside Out: Strategies for Teaching Writing ( ${ }^{\text {th }}$ Ed.): Heinemann. [Available Online] Retrieved on October 3, 2015 from: http://www.heinemann.com/shared/onlineresources/e04195/inside_ou t $4 \mathrm{e}$ ssample_chapter.pdf

38. Kitchakarn, O. (2012). Using Blogs to Improve Students' Summary Writing Abilities. Turkish Online Journal of Distance Education, 13(4), 209-219. [Available online] Retrieved from http://files.eric.ed.gov/fulltext/EJ1000423.pdf

39. Krajka, J. (2012). Web 2.0 Online Collaboration Tools As Environments For Task-Based Writing Instruction. Egitim Bilimleri Fakultesi Dergisi, 45(2), 97. [Available online]Retrieved from http://dergiler.ankara.edu.tr/dergiler/40/1731/18387.pdf

40. Lee, Y.-H., Hsieh, Y.-C., \& Ma, C.-Y. (2011). A Model Of Organizational Employees' E-Learning Systems Acceptance. Knowledge-based systems, 24(3), 355-366. [Available online] Retrieved March 27, 2016 from: http://www.sciencedirect.com/science/article/pii/S095070511000150 $\underline{4}$

41. Lin, M.-H., Groom, N., \& Lin, C.-Y. (2013). Blog-Assisted Learning in the ESL Writing Classroom: A Phenomenological Analysis. Educational Technology \& Society, 16(3), 130-139. [Available online]Retrieved from http://www.ifets.info/journals/16 3/10.pdf

42. Lin, W.-C., \& Yang, S. C. (2013). Exploring the Roles of Google. Doc and Peer E-Tutors in English Writing. English Teaching, 12(1), 79. [Available online] Retrieved from: http://files.eric.ed.gov/fulltext/EJ1017168.pdf

43. Lombard, R., \& Porto, S. C. (2010). Web 2.0 in the Classroom Technology Leadership in Teacher Education: Integrated Solutions and Experiences (p. 214). [Available Online] Retrieved on September 28 , 2015

from:

https://books.google.com.sa/books?hl=ar\&lr=\&id=2ccfy3H3aJkC\&oi $=$ fnd \&pg $=$ PA2 $14 \& \mathrm{dq}=\mathrm{Web}+2.0+\mathrm{in}+$ the + classroom \&ots=tGMA4v45 Je\&sig $=8$ -

XUG_JuEqhH72hgEAR5YIVIoYg\&redir_esc $=\mathrm{y} \# \mathrm{v}=$ onepage $\& \mathrm{q}=\mathrm{We}$ b\%202.0\%20in\%20the\%20classroom\&f $=$ false

44. Mekki, C. (2012). The Student Awareness Of Writing Skill The Case Study Third Year Students At Biskra University (Master dissertation), Mohamed khieder University, Biskra. [Available Online] Retrieved on August 24, 2016 from: http://dspace.univbiskra.dz:8080/jspui/bitstream/123456789/4604/1/The\%20student $\% 2$ 0awareness\%20of\%20writing\%20skill.pdf 
45. Mohamed, M., \& Zouaoui, M. (2014). EFL Writing Hindrances and Challenges: The case of Second Year Students of English at Djillali Liabes. Journal of Educational and Social Research, 4(3), 149.[Available online] Retrieved on August 27, 2016, from: http://www.mcser.org/journal/index.php/jesr/article/download/2706/2 $\underline{673}$

46. Pae, J.-K. (2011). Collaborative writing versus individual writing: Fluency, accuracy, complexity, and essay score. Multimedia-Assisted Language Learning, 14(1), 121-148. [Available Online] Retrieved on October 6, 2015 from: http://kmjournal.bada.cc/wpcontent/uploads/2013/05/14-1-5Pae.pdf

47. Rosen, D., \& Nelson, C. (2008). Web 2.0: A new generation of learners and education. Computers in the Schools, 25(3-4), 211-225. [Available Online] Retrieved on August 24, 2016 from: http://www.tandfonline.com/doi/abs/10.1080/07380560802370997

48. Said, N. E. M., Yunus, M., Doring, L. K., Asmi, A., Aqilah, F., \& Li, L. K. S. (2013). Blogging to enhance writing skills: A survey of students' perception and attitude. Asian Social Science, 9(16), 95. [Available online] Retrieved from http://www.ccsenet.org/journal/index.php/ass/article/download/32385 /18859.

49. Siemens, G. (2005). Connectivism: A Learning Theory for the Digital Age. [Available online]. Retrieved September 20, 2015 from http://www.itdl.org/journal/jan_05/article01.htm

50. Sofia, H. (2012). Enhancing ESL Learners' Technical English Writing Skills with Google Documents and Blogs -A Research Study. Language in India, 12(4), 440-452. [Available online] Retrieved September 29, 2015 from: http://www.languageinindia.com/april2012/sofiagoogledocsfinal.pdf

51. Solomon, G., \& Schrum, L. (2007). Web 2.0: New tools, new schools. ISTE (Interntl Soc Tech Educ).Retrieved September 11,2015 from https://books.google.com.sa/books?id=ZKKQMLir_mMC\&printsec= frontcover \&hl=ar\#v=onepage \&q\&f=false

52. Solomon, G., \& Schrum, L. (2011). Web 2.0 how-to for educators. International Society for Technology in Education. [Available Online] Retrieved September 16, 2015 from: http://www.ebrary.com

53. Speck, B. W. (2002). Facilitating Students' Collaborative Writing. ASHE-ERIC Higher Education Report. Jossey-Bass Higher and Adult Education Series: ERIC. [Available Online] Retrieved October 29, 2015 from: http://files.eric.ed.gov/fulltext/ED466716.pdf

54. Storch, N. (2005). Collaborative writing: Product, process, and students' reflections. Journal of second language writing, 14(3), 153- 
173. [Available Online] Retrieved October 29, 2015 from: http://englishunisma.com/wp-content/uploads/2012/11/Journal-ofSecond-Language-Writing-18.pdf

55. Suwantarathip, O., \& Wichadee, S. (2014). The Effects of Collaborative Writing Activity Using Google Docs on Students' Writing Abilities. Turkish Online Journal of Educational Technology-TOJET, 13(2), 148-156. [Available online]Retrieved from http://eric.ed.gov/?id=EJ1022935

56. Ting, A. (2015). A Study of Taiwanese College Students' Responses to a Blog-based English Writing Project and its Effectiveness. Literacy Information and Computer Education Journal (LICEJ), 6(2), 1938-1944. [Available online] Retrieved from: http://infonomics-society.org/wp-content/uploads/licej/publishedpapers/volume-6-2015/A-Study-of-Taiwanese-College-Students.pdf

57. Venkatesh, V., \& Davis, F. D. (2000). A Theoretical Extension Of The Technology Acceptance Model: Four Longitudinal Field Studies. Management science, 46(2), 186-204. [Available online] Retrieved March 27, 2016 from: https://os3.nl/_media/20112012/venkatesh_and_davis___a_theoretical_extension.pdf

58. Witteman, H. O., \& Zikmund-Fisher, B. J. (2012). The Defining Characteristics Of Web 2.0 And Their Potential Influence In The Online Vaccination Debate. Vaccine, 30(25), 3734-3740. [Available online] Retrieved on August 24, 2016, from https://experts.umich.edu/en/publications/the-definingcharacteristics-of-web-20-and-their-potential-influe

59. Wu, H.-J., \& Wu, P.-L. (2011). Learners' Perceptions on the Use of Blogs for EFL Learning. Online Submission. [Available online] Retrieved from: http://files.eric.ed.gov/fulltext/ED524902.pdf

60. Yunus, M. M., Tuan, J. L. K., \& Salehi, H. (2013). Using Blogs To Promote Writing Skill In ESL Classroom. arXiv preprint arXiv:1305.6358. [Available online] Retrieved from http://arxiv.org/ftp/arxiv/papers/1305/1305.6358.pdf

61. Zhou, W., Simpson, E., \& Domizi, D. P. (2012). Google Docs in an Out-of-Class Collaborative Writing Activity. International Journal of Teaching and Learning in Higher Education, 24(3), 359-375. [Available online] Retrieved from http://files.eric.ed.gov/fulltext/EJ1000688.pdf 